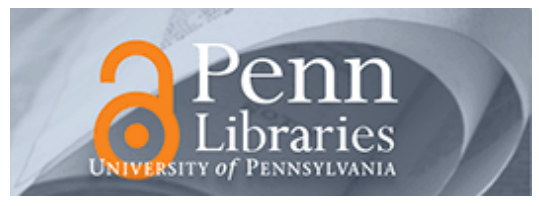

University of Pennsylvania ScholarlyCommons

$1-1-1998$

\title{
Authenticity and Unification in Quechua Language Planning
}

Nancy H. Hornberger

University of Pennsylvania, nancyh@gse.upenn.edu

Kendall A. King

New York University

Follow this and additional works at: https://repository.upenn.edu/gse_pubs

Part of the Other Languages, Societies, and Cultures Commons

\section{Recommended Citation}

Hornberger, N. H., \& King, K. A. (1998). Authenticity and Unification in Quechua Language Planning.

Retrieved from https://repository.upenn.edu/gse_pubs/60

Reprinted in Language, Culture and Curriculum, Volume 11, Issue 3, 1998, pages 390-410.

This paper is posted at ScholarlyCommons. https://repository.upenn.edu/gse_pubs/60

For more information, please contact repository@pobox.upenn.edu. 


\title{
Authenticity and Unification in Quechua Language Planning
}

\begin{abstract}
With more than ten million speakers and numerous local and regional varieties, the unification and standardization of Quechua/Quichua has been a complicated, politically charged, and lengthy process. In most Andean nations, great strides have been made towards unification of the language in recent decades. However, the process is far from complete, and multiple unresolved issues remain, at both national and local levels. A frequent sticking point in the process is the concern that the authenticity of the language will be lost in the move towards unification. This paper examines the potentially problematic tension between the goals of authenticity and unification. One case examines an orthographic debate which arose in the process of establishing an official orthography for Quechua at the national level in Peru. The second case study moves to the local level and concerns two indigenous communities in Saraguro in the southern Ecuadorian highlands where Spanish predominates but two Quichua varieties co-exist. The final section considers the implications of these debates and tensions for language planning and policy.
\end{abstract}

Disciplines

Other Languages, Societies, and Cultures

Comments

Reprinted in Language, Culture and Curriculum, Volume 11, Issue 3, 1998, pages 390-410. 


\title{
Authenticity and Unification in Quechua Language Planning
}

\author{
Nancy H. Hornberger
}

Graduate School of Education, University of Pennsylvania, 3700 Walnut Street, Philadelphia, PA 19104-6216, USA

\author{
Kendall A. King \\ Multilingual Multicultural Studies Department of Teaching and Learning, New \\ York University, 239 Greene St, New York, NY 10003-6674, USA
}

With more than ten million speakers and numerous local and regional varieties, the unification and standardisation of Quechua/Quichua has been a complicated, politically charged, and lengthy process. In most Andean nations, great strides have been made towards unification of the language in recent decades. However, the process is far from complete, and multiple unresolved issues remain, at both national and local levels. A frequent sticking point in the process is the concern that the authenticity of the language will be lost in the move towards unification. This paper examines the potentially problematic tension between the goals of authenticity and unification. One case examines an orthographic debate which arose in the process of establishing an official orthography for Quechua at the national level in Peru. The second case study moves to the local level and concerns two indigenous communities in Saraguro in the southern Ecuadorian highlands where Spanish predominates but two Quichua varieties co-exist. The final section considers the implications of these debates and tensions for language planning and policy.

\section{Introduction}

With more than ten million speakers and numerous local varieties, the unification and standardisation of Quechua/Quichua has been a complicated, politically charged, and lengthy process. ${ }^{1}$ In most Andean nations, great strides have been made towards unification of the language in recent decades. However, the process is far from complete, and multiple unresolved issues remain, at both national and local levels. A frequent sticking point in the process is the concern that the authenticity of the language will be lost in the move towards unification. Often the goal of unifying the language corpus is perceived as threatening to, and incompatible with, the aim of promoting and protecting what is considered by certain regional, ethnic, or interest groups to be the 'authentic' variety of the language. This paper seeks to provide insight into the tension between the goals of authenticity and unification, and to explore ways in which language planning and policy can both avoid and resolve the problems arising from this friction.

We take authenticity and unification as language planning goals because, as we will show below, these are the terms in which Quechua speakers and advocates talk about the language and their goals for it. In Hornberger's framework of language planning goals, types, and approaches, authenticity and unification both fall primarily within corpus cultivation planning, or language 
planning directed towards 'the cultivation of a language's form for additional functions' (1994: 80); and more specifically, they fall within what Cooper has called renovation, which 'permits language codes to serve old functions in new ways' (1989: 154). As we will see below, however, both unification and authenticity extend beyond corpus cultivation planning into other language planning dimensions as well.

Unification in the sense we use it here goes beyond Nahir's original definition of 'terminological unification' as 'establishing unified terminologies ... in order to reduce communicative ambiguity, especially in the technological and scientific domains' (1984: 308). Here we take unification to mean not only lexical terminological unification, but also the orthographic, morphological, and syntactic unification of the language for additional functions, involving aspects of both standardisation and graphisation. ${ }^{2}$ Thus, unification entails corpus policy planning in addition to corpus cultivation planning (Hornberger, 1994).

Authenticity as a language planning goal is perhaps more difficult to define. It is linked to purification, which Nahir defines as prescribing usage in order to protect the language from foreign influence (external purification) and from deviation from within (internal purification) (1984: 299-301). Yet authenticity implies not only cultivation of a language's corpus, but of its status as well, as speakers seek to ensure the maintenance or revitalisation of what they consider to be the authentic variety; thus authenticity entails status cultivation planning in addition to corpus cultivation planning (Hornberger, 1994).

Examination of the dictionary definition of authenticity provides insight into the term's potency, not only as an issue in language planning, but also as a rhetorical device. That which is authentic is 'not false or copied', but rather 'genuine [or] real' (Random House, 1983). Designating a particular language variety as authentic, then, implies that it is uniquely legitimate. For language planners, this means that a certain variety should be privileged in instructional planning and policy decisions. For some language users, the claim of authenticity suggests that a particular variety of the language is not artificially constructed, but interwoven with their own traditions and unique heritage. Clearly, assertions of authenticity hold important implications, and, as we shall demonstrate below, are often highly charged - both emotionally and politically. The claim of authenticity is also, however, one for which there exist no clear linguistic criteria.

By definition, unification of a language entails the manipulation of the language corpus. It also frequently involves explicit efforts to establish the revised (and 'authentic') variety of the language as the norm. However, for certain regional or interest groups, attempts to promote the new variety may lead to the perception that their own ('authentic') variety is under attack.

Planning efforts involving threatened languages such as Quichua/Quechua often confront the issue of authenticity. As Dorian has documented, controversies over linguistic purism and authenticity, which are common among recently normed languages, can 'threaten the very success of the effort to promote a standard language' (1994: 479-80). Indeed, as we shall illustrate below, it is not uncommon for the goals of authenticity and linguistic unification to conflict, and as a result be problematic for language planning efforts in a variety of ways. 
This paper analyses two recent language planning cases where issues of authenticity and unification are of critical interest. One case examines an orthographic debate which arose in the process of establishing an official orthography for Quechua at the national level in Peru, specifically, the three versus five vowel debate. ${ }^{3}$ The role of various interest groups in the debate and the arguments they have made are highlighted, with particular attention to issues of authority, authenticity, and autonomy of the language. ${ }^{4}$ The second case study moves to the local level and concerns two indigenous communities in Saraguro in the southern Ecuadorian highlands where Spanish predominates but two Quichua varieties co-exist: the standardised Unified Quichua learned by the younger, better educated members, and the local variety, known as 'authentic Quichua', spoken by the older and generally more remotely situated Saraguros. The tensions between speakers concerning language purity and authenticity are discussed and analysed. A final section considers the implications of these debates and tensions for language planning and policy.

\section{Background to Quechua Officialisation and Orthography in Peru}

At six million, Peru has the highest absolute number of indigenous language speakers of all the South American countries (López, 1995: 36). Approximately 5.2 million are Quechua speakers, comprising somewhat under a quarter of Peru's total population over age five. Yet despite their large numbers, the oppression and exclusion of Quechua speakers has been a constant fact of Peruvian society. Thus, it was of great significance when, in 1975, as part of a larger programme of socially progressive reforms undertaken by the Revolutionary Government of Juan Velasco Alvarado, Quechua was declared an official language co-equal with Spanish.

Although full-fledged Quechua officialisation turned out to be short-lived, it nevertheless served as an important spur for government and non-government institutions alike to engage in the teaching of Quechua literacy and the development of materials and texts in Quechua. During the 1980s, these efforts confronted a series of problems in applying the official Quechua alphabet, and differences of approach in resolving them emerged. Foremost among the problem areas was the debate over whether Quechua should be written with the traditional five vowels $(\mathrm{a}, \mathrm{e}, \mathrm{i}, \mathrm{o}, \mathrm{u})$, reflecting a shared orthography with Spanish, or with the more linguistically 'correct' three vowels $(a, i, u)$, corresponding to the vowel phonemes of the language.

\section{Groups engaged in teaching and publishing in Quechua}

The main interest groups in the debate were the individuals and institutions that were most involved in teaching and publishing in Quechua. These included Peruvian linguists, bilingual education project personnel, and the Peruvian Academy of the Quechua Language. A word of introduction about each interest group and a brief outline of their socioeconomic, educational, regional, and ethnic differences will provide some background to the debate.

Many of the Peruvian linguists most active in the language planning arena were professors at San Marcos University or the Catholic University, both in the country's capital, Lima, and both among the oldest and most prestigious of Peru's 
universities. These linguists were actively involved with major experimental bilingual education projects, including the Ayacucho project begun in 1964 and the Puno project begun in 1977.

Another major bilingual education project was that of the North Americanbased international Summer Institute of Linguistics, which has been working in Peru since 1946. The objective of this missionary body, in Peru as in the rest of the world, is to translate the Bible into every existing language to enable every person on earth to have access to the Word of God. The task of Bible translation has involved the SIL in developing writing systems for hitherto unwritten languages and in providing bilingual education for hitherto nonliterate populations (Townsend, 1972). As a matter of policy, the SIL undertakes work only under official agreement with the national government; in Peru there has been a close affiliation between the SIL and the Ministry of Education since SIL's earliest beginnings. Most of the SIL's earlier energies were directed towards the many languages of the Amazon region in northern Peru, although they sponsored a Quechua-Spanish bilingual education project in Ayacucho for five years beginning in 1965; more recently they have been working in Quechua in several departments of Peru (specifically, Ancash, Cajamarca, Cerro de Pasco, Huánuco, Junín, Lambayeque, and San Martín).

Another interest group is the Peruvian Academy of the Quechua Language, founded in 1953 in Cusco, the ancient capital of the Inca Empire. The Academy is dedicated to the promotion of Quechua through such activities as speaking it in public events; publishing Quechua writings (e.g. Inka Rimay); teaching Quechua; the awarding of a National Cusco Prize for a Quechua Novel, Poem, Story and Drama; and producing a unified international Quechua grammar and dictionary (Academia Mayor de la Lengua Quechua, 1995).

Socioeconomic status, educational background, regional affiliation, and ethnicity are differentiating characteristics among these interest groups though, as with any sociological characteristics, the reality is far more complex than any broad generalisation would imply. The generalisation that the SIL linguists enjoy the highest socioeconomic status and the Quechua Academy members the lowest, based on the relative wealth of the US, Lima, and the Peruvian highlands respectively, masks the fact that the North American missionary endeavour is a far cry from the affluence of other sectors of North American society; or that a Lima linguist's professional salary may provide far less means than the landholdings of an Academy member, particularly in times of excruciating economic crisis such as Peru has experienced in the past few decades. The generalisation that the SIL linguists tend to be trained outside Peru, or that the Peruvian linguists tend to have a higher level of education than the Quechua Academy members, belies the fact that many Peruvian linguists have done graduate study or obtained graduate degrees in the US or Europe and that some of the Academy members hold advanced degrees, as well as obscuring the fact that one's level of education need not be dependent only on years of formal study.

Again, the generalisation that the regional affiliations of the three groups are foreign, capital city, and Department of Cusco, respectively, oversimplifies the sense of affiliation which they may have. None of the three groups adopts a parochial affiliation to only the region of their origin: the Academy members look 
beyond the Cusco Quechua region to the rest of the Quechua speaking world; the Peruvian linguists look beyond the capital to the nation as a whole and even the Andean nations as a group; and the SIL linguists couple their global and country-of-origin perspective with a focus on the national perspective within which they work. In the same way, each group's ethnicity is as much a matter of the group with whom they identify as of the group with whom they are identified. The Peruvian linguists are identified primarily with the Spanish speaking criollo 'creole' coastal culture, and the Academicians with Quechuaspeaking indigenous highland culture. However this does not preclude the Peruvian linguists being ideologically closer to the indigenous highland populations than their Academy counterparts. Similarly, foreign SIL linguists generally go a long way towards identifying with the local Quechua ethnicity and ensuring that their work incorporates genuine voices of indigenous Peruvians; they usually learn to speak the local Quechua variety.

\section{Quechua speakers as an invisible interest group}

Perhaps the differences among the above three groups are best summed up in the terms by which they refer to the fourth, in many ways invisible, interest group: the Quechua-speaking population of Peru. The Peruvian linguists/bilingual education specialists most often refer to the Quechua speakers as campesinos 'peasants', while the Quechua Academy members use the term indigenas 'indigenous people' (e.g. Debate, 1987: 170,172). In part, this difference is simply a reflection of the difference in generation between the two groups: the younger generation, the Peruvian linguists / bilingual education specialists, have adopted the term introduced after 1968 by the Revolutionary Government specifically to replace the term indigena, while the older generation, the Quechua Academy members, have not. However, both the government's terminology planning and the interest groups' use of the terms also reflect ideological stances based on socioeconomic, regional, and ethnic differences: campesino identifies Quechua speakers primarily by their socioeconomic position in society while indigena defines them primarily by linguistic and cultural characteristics; campesino is a term legislated upon the highlands from Lima, while the term indigena has a certain regional historical force deriving from the indigenist movement of the early 20th century (Tamayo Herrera, 1980, 1982).

SIL linguists, on the other hand, most often refer to the Quechua-speaking population as Quechua speakers (e.g. ILV, 1983:3), vernacular speakers (e.g. ILV, 1983: 5), native speakers (e.g. ILV, 1983: 6), readers (e.g. Debate, 1987: 148), or users (e.g. ILV, 1983: 9), all terms which the other two groups use as well. Consistent with SIL's goals in Peru, the emphasis in this choice of terms is not on Quechua speakers' cultural, political, or economic identity, but on them as speakers, readers and writers of the language.

\section{The Three versus Five Vowel Debate}

The different interests these groups represent informed and influenced the arguments they made in the three versus five vowel debate of the 1980s. In the following discussion, we will take up first the arguments directly addressing the structure of the language and the language planning process, which constituted 
the specific terrain of the debate. Following that, we will turn to the underlying issues of authority, authenticity, and autonomy, as they were expressed in the debate.

\section{Language structure and language planning process}

The crux of the linguistic argument in the debate is that Quechua has only three vowel phonemes, /i/, /a/, and /u/, while [e] and [o] occur as allophones of $/ \mathrm{i} /$ and $/ \mathrm{u} /$ when in the proximity of the uvular consonant /q/ (or its aspirated or glottalised counterparts, / $\mathrm{qh} /$ and $/ \mathrm{q}^{\prime} /$ ). The Peruvian linguists, therefore, argued that, on the basis of the phonemic principle in designing alphabets (whereby each sound that is distinctive to the native speaker is represented by one and only one letter; cf. Pike, 1947:208), the Quechua alphabet should have three vowels (i, a, u); the native speaker will automatically pronounce the written $i$ as [e] and the written $u$ as [o] when they occur in proximity to $q$, $q$ h, or $q$ ' (Debate, 1987:179; Jung \& López, 1987: 588; López Flores, 1987:9-11).

The Quechua Academy members' focus was elsewhere, however. On the basis of their accumulated 30 years of writing practice using a five-vowel Quechua alphabet (see Hornberger, 1993 for more on the alphabets), the Academy members formulated the rule from the other end. For them, the rule is that for writing Quechua, $e$ and $o$ go with $q$, and $i$ and $u$ go with $k$; thus, if you change the $e$ in qella 'lazy' to $i$, you must also, by the writing rule, change the $q$ to $k$, yielding killa 'moon', a different word altogether. In order to write qella, they argued, they need all five vowels since, in Cusco at least, they pronounce all five (Debate, 1987: 165).

The Peruvian linguists pointed out that it is not only in Cusco that all five are pronounced, but also, for example, in Puno, Ayacucho, Ancash, and Cajamarca (Debate, 1987: 161, 166). For these linguists, it was important to distinguish writing from pronunciation (Debate, 1987: 162-163). They used the comparison of Cusco Spanish pronunciation of acto 'act' as [ajto] rather than [akto] and of apto 'apt' as [afto] rather than [apto] to make the point that there need not be (and rarely is) an exact correlation between writing and pronunciation (Debate, 1987: 163). Academy members, on the other hand, started from the premise that one should not write one way and pronounce another (Debate, 1987: 166). Furthermore, they argued that Quechua has been written with five vowels ever since the colonial period (Debate, 1987: 179).

The SIL linguists appeared to fall somewhere between the Peruvian linguists and the Academicians. On the one hand, they recognised that Quechua had only three vowel phonemes in the past and that the ideal alphabet for any language follows the phonemic principle. On the other, they also placed great weight on native speaker preference in instances of conflict between linguistic precision and native speaker acceptance; and they emphasised the evidence for five vowel phonemes in several Quechua varieties (Weber, 1987a: 8).

The Academy members cited as justification for the use of five vowels the fact that it has been written that way for 400 years since the Spanish arrived and began to write Quechua, and the SIL linguists cited the preferences of the new native-speaking readers and writers they work with for five vowels. In contrast, 
the Peruvian linguists/bilingual education specialists cited their numerous publications using three vowels, noting that they are practically the only ones who produce written material in Quechua (Jung \& López, 1987: 591; also Primer Congreso, 1987: 583-584). Furthermore, whereas the Academy members reported that they were totally accustomed to the use of the five vowels and the SIL linguists reported that native speakers clearly preferred the use of five vowels (ILV, 1983: 9), the Peruvian linguists/bilingual education specialists pointed to evidence from the bilingual education projects that the three vowel alphabet works (Debate, 1987: 174), citing the fact that children reading Quechua have no trouble reading the three vowels and pronouncing $e$ and $o$ near $q$, whether they are just learning to read for the first time or already know how to read in Spanish (Jung \& López, 1987: 586, 588). Thus, on the one hand, all three groups argued for a decision based on already existing implementation and native speaker acceptance, but on the other, they each cited different implementation precedents.

Similarly, linguists/bilingual education specialists and Academy members were all dissatisfied with voting as a means of making language planning decisions, but they registered their dissatisfaction over different votes. One linguist noted that while others said they could not respect the three-vowel decision taken at a 1983 Workshop because it was decided by a vote, he could say the same about the earlier five-vowel decision of the 1975 Quechua Commission, which was also decided by a vote with only one more vote for five vowels than for three. If we are unable to reach agreement by objectively weighing the arguments, he said, we have no alternative but to decide by a vote, unsatisfactory as that may be (Cerrón-Palomino in Debate, 1987: 160). Yet, the sequence of meetings and conflicting decisions in the three versus five vowel debate demonstrates just how unsatisfactory voting was as a means of reaching agreement. As in most political debates, it seemed that there were always procedural grounds on which one or another of the interest groups might challenge the validity of decisions taken, and the cycle of new meetings and different votes was potentially endless.

\section{Authority, authenticity, and autonomy}

Indeed, as the debate progressed, it appeared that much deeper issues were at stake: namely the basis of authority on the language, and the defence of its authenticity and autonomy. The Peruvian linguists/bilingual education specialists - most of whom are not fluent speakers of either Quechua or Aymara defended the need for specialised scientific study to inform language planning decisions. The SIL linguists derived their authority from their study of the language and their pedagogical work and literature production with native speakers. In contrast, the Quechua Academy members saw the ability to speak Quechua as fundamental to having the authority to decide on it, and periodically challenged the authority of the non-Quechua speakers. Indeed, the actual use of Quechua in these discussions was all too infrequent.

Another contested basis of authority, in addition to speaking and scholarship in Quechua, was the historicity of Quechua (Stewart, 1968). Whereas the members of the Quechua Academy took Cusco Quechua to be the 'mother 
language' of all the Quechua varieties, basing their view on the political and social history of the Inca Empire, the linguists - basing themselves on historical linguistic analysis, archaeological evidence, and Andean social history established the earliest origins of Quechua to have been in the central part of Peru and viewed Cusco Quechua to be only one of several varieties belonging to later evolutions of Quechua (Parker, 1963; Torero, 1974). For the Cusco Academy members, Cusco Quechua was the standard against which to measure all Quechuas, and they challenged the Lima linguists' knowledge of Quechua when it was based only on exposure to Puno Quechua (through the bilingual education project in Puno). The Lima linguists, by contrast, sought to convince the Cusco Academy members with linguistic evidence that Puno Quechua may represent an older form of Quechua than that spoken in Cusco (Debate, 1987: 173, 175). Their purpose in doing so was not to denigrate Cusco Quechua, but to argue that regionalism should play no part in their joint efforts to defend the Quechua language (Debate, 1987: 160).

Indeed, the defence of the Quechua language's authenticity and autonomy emerged as of fundamental importance to all the interest groups in the three versus five vowel debate. The Peruvian linguists sought to base their decisions on respect for the language, the search for the truly authentic Quechua that is not contaminated by contact with Spanish, and the attempt to be as objective as possible in analysing Quechua (Debate, 1987:160,162, 174).

The Peruvian linguists/bilingual education specialists' defence of Quechua's authenticity includes vigilance for its purity from the influence of Spanish. Authenticity, they argued, will be found in those who have not been conditioned by the pressures of the western world (Debate, 1987: 170,171, 174, 178). They affirmed the standardisation of the authentic Quechua; that is, not the Quechua of the bilingual mestizo, but the Quechua of the rural sector, the monolingual campesinos. To argue for writing Quechua with five vowels, they suggested, is to impose Spanish conventions on Quechua (Jung \& López, 1987: 590), making Quechua subservient to Spanish, just another form of colonialism (Primer Congreso, 1987: 583; Debate, 1987: 164; López Flores, 1987: 12-13). They asserted that the highest authority on pronunciation must be the Quechua speaker who is not exposed to any foreign linguistic influence; and they noted that the native Quechua speakers who have produced books in Quechua for the bilingual education projects have had no trouble using three vowels (Jung \& López, 1987: 591).

In addition, the Peruvian linguists/bilingual education specialists argued that guarding Quechua's autonomy includes defending Quechua against anti-scientific analyses. Thus, they objected to Academicians' suggestion that the origin of Quechua is in onomatopaeic sounds, imitating the languages of animals (as others have claimed about the origin of human language in general). Such a theory, they said, leaves Quechua open to attack as being nothing more than the language of wild animals and birds, as Peruvian Hispanicist intellectuals often maintain (Debate, 1987: 175, 177).

Defending Quechua's autonomy not only includes adopting an objective stance towards analysing it, but also seeking ways to build its range of use. The Peruvian linguists/bilingual education specialists called for a stance which 
would seek to make Quechua a vehicle of national communication, not only in the schools, but also in the university, on television, in the newspapers, and in government offices (López Flores, 1987: 13). They were also conscious of sustaining and promoting Quechua use at an international level. They suggested that the use of the three vowel alphabet could contribute to Quechua unification/standardisation at both the national and the international level, since it is understandable not only in Cusco, Puno, and so on, but also where only three vowels are pronounced (e.g. in Alto Napo (Peru) and in Ecuador; Jung \& López, 1987 : 590).

SIL linguists also recognised the importance of the goals of unification/standardisation among Quechua varieties and preservation of Quechua language and culture, but it is fair to say that they took a view which was both more locally oriented and more bilingual. In this view, the autonomy and authenticity of Quechua depend, not on its standardisation according to one uniform norm, but on first recognising and developing the functional range of Quechua in its regionally distinct varieties. The argument was that it is precisely the regional distinctives of each variety which serve as symbols of ethnic solidarity for Quechua speakers, and that to undercut those distinctives by unification/standardisation would erode the fundamental reason for Quechua speakers to speak Quechua (Weber, 1987b: 11-22). Furthermore, applying insights from the case of Nahuatl and Spanish in Mexico (Hill \& Hill, 1980), it was argued that to impose restrictions on borrowing from Spanish into Quechua would project a purist attitude which might ultimately have the effect of hastening the death of Quechua (Weber, 1987b: 23-33).

For the members of the Peruvian Academy of the Quechua Language in Cusco, defending Quechua's authenticity and autonomy meant something slightly different from either of the above approaches. Like the Peruvian linguists, they are vigilant against incorporation of Spanish lexicon; indeed, many of them command an extremely rich Quechua vocabulary, born of years of collecting words from the most remote areas of the highlands. Like the Peruvian linguists, too, some of them accept that the basis for study of Quechua must be the indigenous Quechua speaker (Villasante in Debate, 1987: 169, 176; but cf. Farfán, p. 171, who invokes the mestizo as the model). At the same time, however, sharing the SIL's more bilingual view, they explicitly include themselves among Quechua speakers and argue for language planning decisions to be responsive to their needs as well (Debate, 1987: 171). From their perspective, different from either the SIL or the Peruvian linguists, the authenticity of Quechua has more to do with freedom from contamination from Lima and fidelity to Cusco norms than with freedom from Spanish influence and bilingual speakers or with fidelity to the various local varieties of Quechua.

This stance related directly to the Academicians' view of Quechua's autonomy, as well. They were wary, with good historical reason, of domination by Lima; and they perceived the activism of the Lima linguists as nothing more than a 'new domination under the pretext of science' (Espinoza Navarro, Language and Culture Workshop, Cusco, 20 July 1987). From their perspective, the fact that the Ministry of Education had approved the recommendations of the 1983 
Workshop despite the objections of Cusco representatives was evidence that the Ministry was being manipulated by the Lima linguists (Debate, 1987: 169).

Fishman has noted that 'all ethnocultural entities have elites of their own, and these are often the most reluctant to change the status quo vis-à-vis writing systems' (1988: 283). It is difficult to enforce a change of writing system on the inertia of older readers and writers, he maintains, especially when no dramatic change in social function, ethnic identity, or social status goes along with the change. Considered in this light, it is not surprising that the Academy members, many of whom have, after all, been writing Quechua for longer than the other interest groups, should resist a change in their writing system. For them, there was no perceived benefit in such a change; indeed, there was instead the threat of more domination from Lima.

Underlying the debate over how many vowels Quechua should be written with was a more fundamental debate about the authenticity and unification of Quechua. Competing claims to authentic knowledge of the language were based on speaking knowledge of the language, scholarship on it, or the historicity of particular varieties. Concerns for preserving the authenticity of Quechua revolved around protecting it from the influence of Spanish and from anti-scientific analyses, concerns which were not necessarily shared by all interest groups to the same degree. The unification/standardisation of Quechua was recognised as a desirable goal for sustaining and promoting its use at national and international levels, but such a goal was also perceived to embody a potential threat to local and regional ethnic and political affiliations and solidarity. We will return to these issues below, after first considering the Ecuadorian case.

\section{Quichua Revitalisation and Education in Saraguro, Ecuador}

With a population of $11,476,000$ and a land area of 270,670 square kilometres, Ecuador is one of the smaller Andean republics (Inter-American Development Bank, 1997). Yet with three distinct ecosystems occupied by ten different indigenous nations, Ecuador is also among the most ecologically, culturally, and linguistically diverse nations of South America. Indigenous people constitute between $20 \%$ and $45 \%$ of the Ecuadorian population (Macas, 1993; von Gleich, 1994; CIA Fact book, 1997). Of the ten indigenous nations, the Quichua-speaking nation is by far the largest, with over two million members. ${ }^{5}$ Despite such diversity, Ecuadorian indigenous groups have been unusually successful in effectively organising themselves for the attainment of a range of collective goals. Perhaps the most important of these goals, in terms of policy changes which impact the present experience and future orientation of much of the indigenous population, has been the advancement of indigenous bilingual education.

As environmentally devastating oil exploration and extraction ravaged parts of the Ecuadorian Amazon in the early 1970s, Amazonian indigenous groups formed ethnically-based organisations to defend their habitats. ${ }^{6}$ Following the Amazonian example and motivated by their own needs, indigenous groups from other regions began to organise politically in the 1970s and 1980s. Their concerns were primarily the protection and control of natural resources, and the recognition of political and cultural rights (cf. Ryan, this volume). Organisational and consciousness-raising efforts culminated in 1986 when the Confederación de 
Nacionalidades Indígenas de Ecuador (CONAIE) ('Confederation of Indigenous Nationalities of Ecuador') was established and legally recognised as the representative and advocacy body for all indigenous persons in the country.

As organisation across the indigenous sector increased, so did indigenous peoples' demands for linguistically appropriate and culturally relevant education for their children. Largely in response to internal indigenous demands, and to a lesser extent, international political pressure, several major national policy changes during the 1980s allowed for the development of indigenous bilingual education. In 1980 the state accepted proposals from non-governmental organisations for indigenous language education projects (Yáñez Cossío, 1991); in 1981 the state officialised bilingual intercultural education in schools which predominantly served indigenous populations (von Gleich, 1994); and in 1983, Article 27 was added to the constitution providing for 'the use of native languages as first languages of education and the use of Spanish as a second language or language of intercultural communication' in predominantly indigenous areas (Yáñez Cossío, 1991:58). As a result of these significant legal reforms, several large-scale experimental, bilingual education programs were implemented, such as the Ministry of Education's 'Macac' Education Model and the German-funded Proyecto de Educación Bilingüe Intercultural (PEBI) ('Intercultural Bilingual Education Project').

Perhaps the most significant change in government policy was the establishment of the Dirección Nacional de Educación Indígena Intercultural Bilingüe (DINEIIB) ('Department for Indigenous Intercultural Bilingual Education') in 1988. Composed of members of the Ministry of Education and Culture, as well as CONAIE representatives, DINEIIB administers education in areas in which the population is more than half indigenous, and is charged with guaranteeing the unity, quality, and efficiency of indigenous education throughout Ecuador (DINEIIB, 1991). The shift in authority to DINEIIB meant that indigenous schools would be directly under indigenous leadership and marked the 'first time in the educational history of Latin America that a Hispanic government allowed and supported the establishment of an independent educational administration for the indigenous populations, transferring the right to develop culturally appropriate curricula and independent teacher-training and selection methods in cooperation with the Indian communities' (von Gleich, 1994: 96).

\section{The unification of Quichua in Ecuador}

Concomitant with the indigenous organisational developments and the educational policy changes of the last three decades was the standardisation of Quichua and the creation of what came to be known as Quichua Unificado or Unified Quichua. With the technical support of the Indian Education Research Center at the Catholic University of Quito, representatives of speakers of the different Ecuadorian varieties of Quichua agreed upon a unified variety of Quichua in 1981 (Montaluisa, 1980; in von Gleich, 1994). With twenty consonants and three vowels, the orthography of Quichua Unificado differs significantly from Spanish. Quichua language planners attempted to expunge Spanish loan words from the language, either by replacing them with a regionalised Quichua lexical item or by creating a neologism. While representatives from many areas of the 
country were included in the unification process, concern has also been expressed that certain regions, such as the Province of Imbabura, just north of the capital city, Quito, were over-represented in the meeting and thus exerted disproportionate influence on the unified variety (Sarango Macas, personal communication, 4 April 1995). Although there is limited amount of disagreement with the decisions of the representatives and linguists concerning Quichua Unificado, there is no organised dissent or alternative system which challenges it.

The creation of Quichua Unificado codified the writing system; this major step towards standardisation of Quichua was intended to facilitate the acquisition of literacy and the development of Quichua literature, as well as assist the maintenance and even revitalisation of the language. While unified in written form, it was accepted and expected that the regional varieties would continue to differ in their spoken form (CONAIE, 1990). It is unlikely, however, that Quichua language planners entirely foresaw how use and instruction of the new variety would play out in the nation's diverse Quichua communities.

\section{Quichua in two Saraguro communities}

The Saraguros reside in roughly 60 communities located principally in the southern highlands of the Loja province, and in lesser numbers in the south-east lowlands of the Zamora-Chinchipe province. Numbering approximately 20,000, the Saraguros are part of the Quichua nation, but also constitute an ethnically distinct group, nationally and locally identifiable as such by their clothing and ornate silver jewellery (Belote, 1984).

Despite the maintenance of a strong and separate indigenous cultural identity, the Saraguros are increasingly Spanish dominant. Although language competencies vary by community, the vast majority of Saraguro children are now Spanish dominant, and many adults of child-bearing age have only aural competence in Quichua. In recent years, among some Saraguros there has been increasing concern regarding the linguistic situation and a growing desire to reverse the trend towards Quichua loss and Spanish monolingualism. To this end, a number of communities have implemented language revitalisation programs which instruct Quichua as a second language in their public elementary schools, and some members are making a concerted effort to instruct and use Quichua in the wider community. The language revitalisation efforts have been well-received and beneficial in numerous linguistic and non-linguistic ways (King, 1997). However, the efforts have also generated a considerable amount of friction, much of which can be traced to concerns surrounding issues of authenticity and unification. Some of the tensions and repercussions from the introduction of Unified Quichua in two Saraguro communities, Lagunas and Tambopamba, are addressed in the following paragraphs.

\section{Two communities}

The residents of the community of Lagunas were some of the earlier Saraguros to engage in extended contact with the non-indigenous world. This is due, to a large extent, to the community's location adjacent to the Pan American Highway and just above the town of Saraguro, the largest commercial centre of the region. Lagunas was one of the first communities to send its children to primary and 
secondary school in large numbers and one of the first to have its members go on to higher education in the nation's larger cities. There are a number of professionals in the community and the residents are viewed by many in the region as relatively well-educated and financially well off.

Not coincidentally, the Saraguros of Lagunas were also among the earliest in the region to become bilingual and soon after Spanish dominant. Presently, the residents of Lagunas find themselves in what many feel to be the rather awkward position of uniformly self-identifying as indigenous, yet using Spanish as their principal language of communication. The children of the community are nearly monolingual Spanish speakers, with knowledge of some basic vocabulary and simple commands in Quichua. In general, young adults are Spanish dominant, with limited Quichua speaking skills and partial aural comprehension. Older adults are bilingual; the very oldest among them are Quichua dominant.

In the mid-1980s a group of local indigenous teachers who were dissatisfied with traditional education formed schools in three communities, the second being the Inti Raimi school of Lagunas. One of the primary goals of the schools has been to instruct Quichua and promote its usage, with the larger aim of revitalising Quichua language and 'traditional' Saraguro culture within the community. For more than a decade, the school staff has instructed Quichua to its students, encouraged parents to learn Quichua and use it with their children, and generally attempted to promote the language and language awareness in the community.

Turning to the second community, while a critical factor in the character and development of the community of Lagunas is its location near the Pan American Highway, the relatively remote location of Tambopamba has been equally important in shaping its development and identity. The majority of residents of Tambopamba remain fully engaged in agricultural work, raising cattle and sheep for cash and working small plots of land for familial food consumption. Few adults have attended school for more than two or three years and the number of professionals in the community is very limited. While many of the children in Tambopamba are Spanish dominant, the majority of the adults speak Quichua frequently among themselves and especially in communication with community elders.

Like Lagunas, Tambopamba also has its own elementary school, Huayna Capac. The school's pedagogical orientation and instructional content differ little from the Hispanic schools which serve the non-indigenous population. While there is a limited amount of Quichua instructed at the Tambopamba school, the teachers and the community do not see the school's primary mission to be linguistic and cultural maintenance or revitalisation. And although certainly some members of Tambopamba are concerned with the future of the language, relatively little effort has yet to be focused in this direction and revitalisation efforts remain sporadic and limited in scope (cf. Fettes, this volume).

\section{Language use patterns}

Analysis and comparison of language use patterns within the communities indicates that interesting and significant differences exist. While Quichua is used regularly to meet basic communicative needs within Tambopamba, this is not 
the case in Lagunas, where Quichua has lost many of its communicative uses. In Lagunas, Quichua use is restricted to a small number of very specific functions, namely purposeful practice and instruction within families, and marked expression of ethnic identity. Marked expression of ethnic identity refers to occasions when members diverge from the most communicatively efficient variety (here the language which interlocutors readily understand and speak), Spanish, and opt for the symbolically more potent variety (here Quichua) as part of the negotiation of their identity as 'authentically' indigenous.'

Lagunas parents do not use Quichua naturally with their children, but they do make an effort to teach children Quichua. This generally occurs through the instruction of isolated lexical items. Tambopamba parents, in contrast, do not teach Quichua to their children, nor do they regularly engage in interaction with them in Quichua. Many Tambopamba children do, however, receive substantial exposure to the language, and reside in homes where the language is used regularly among their parents and grandparents.

While they are at school, children from Tambopamba and Lagunas used Quichua in different and telling ways. While students at Inti Raimi used Quichua to play, to show-off, and to be funny, student uses of Quichua at Huayna Capac were unintentional 'slips' which tended to occur at highly emotional moments. Thus, uses of Quichua in Lagunas tended to be self-conscious and often even planned, for example when Quichua is used for explicit instruction or for the marked expression of ethnic identity; Tambopamba residents, in contrast, used Quichua frequently, naturally, and unselfconsciously.

\section{Authenticity and unification in Saraguro}

In addition to varied distribution and uses of Quichua in the two communities, there are additional differences concerning the distribution of the two varieties of Quichua: Unified and 'authentic'. As language revitalisation programs have progressed in Saraguro in the last decade, two distinct varieties have emerged and come into contact, raising the thorny issue of authenticity. The Quichua-asa-second-language pedagogical materials and instruction promote the nationally standardised variety of Quichua - Unified Quichua - which was discussed above. This stands in contrast to what is commonly referred to as 'authentic Quichua', spoken by older residents of Lagunas and many of Tambopamba. Because the children and young adults studying and learning Unified Quichua have neither mastered the phonological system nor lexical particularities of the local variety, these young Saraguros not only learn to read but to speak Unified Quichua. While mutually intelligible to most, there are alternatively both clashes and gaps in communication between the older and younger Quichua speakers in the community, especially in Lagunas.

While 'authentic Quichua' reflects the phonological system of the region, it contains many Spanish loan words and has lost some elements of its morphological structure. Those who have studied Quichua in Cuenca or Quito, generally the younger, better educated, and more politicised of Lagunas and a very few of Tambopamba, tend to speak and promote what they perceive to be the relatively 'pure', standardised variety, while at times criticising the local variety as corrupted and inferior, and lacking una buena estructura ('a good structure'). 
'Authentic Quichua' speakers, in contrast, complain that Unified Quichua is too difficult and at times incomprehensible.

Tension over authenticity and unification, then, runs along two somewhat overlapping dimensions. The first is between older and younger community members in intergenerational communication. For example, some younger adults in Lagunas report that their parents and grandparents refused to speak with them because they could not make sense of all the new words in Unified Quichua, and concomitantly other younger members criticise the Quichua of the elders and believe it is not a good model for themselves or their children to follow. The second area of tension results from the distribution of Unified and 'authentic' Quichua along social and economic class lines. The economically and professionally successful Saraguro, who largely reside in communities close to town such as Lagunas, are more likely to speak Unified Quichua. Indeed, most of the Quichua speakers in Lagunas have purposefully learned the language through individual study or formal schooling, hence acquiring the unified variety. In contrast, less educated, more remotely situated members who reside in communities such as Tambopamba are likely to know and use only 'authentic Quichua'. Friction exists over which communities (or individuals) speak the true and proper Quichua.

Such linguistic and communicative division further fragments a linguistic minority community already embattled by Spanish and stifles contact between two groups of speakers, therefore limiting opportunities for the language to be used and learned. Like many threatened languages, Quichua is believed to have limited economic value. The puristic attitudes expressed by Unified Quichua speakers and advocates may serve to undermine the sentimental and aesthetic appreciation for 'authentic Quichua' and may deter users, who are potentially valuable sources of input for the younger generation, from speaking at all. Tension concerning the authenticity and unification of Quichua not only means that children learning Quichua as a second language will be less likely to benefit from home and community support for the language, but also that the standard will be more slowly negotiated and spread among Saraguros.

While the existence of multiple varieties or dialects of a language in a community is a normal and, indeed, desirable phenomenon, the Saraguro situation is somewhat unusual and potentially problematic because functional distribution of the language varieties is not developing. Rather than cultivating a diglossic situation where Unified Quichua is used for literary or formal purposes while the local variety of Quichua is used for informal or spoken communication, the introduction of Unified Quichua into the community has accentuated and solidified generational, educational, and emerging class differences among Saraguros.

As noted above, use of the term 'authentic' in describing a language or language variety is a slippery one. As cultures and languages are not static, but rather constantly in flux, the label of 'authentic' to one particular variety or trait is often an arbitrary one. This is clear when we examine how the term has been applied to the Quichua varieties in Saraguro. 'Authentic Quichua' contains many Spanish loan words and has lost part of its morphological structure. While Unified Quichua is in fact linguistically more 'pure', in that it is less influenced 
by Spanish, it is perceived as new and inauthentic by many Saraguros. And although 'authentic Quichua' is the variety learned and used naturally in the home and community by many Saraguros, it is perceived as corrupted by Spanish, and hence inauthentic by its critics. The claim of authenticity, then, seems of little descriptive use, but rather works to establish a (fruitless) oppositional discourse wherein promotion of one language variety (and by association, its speakers) as genuine and pure, implicitly degrades another as inauthentic, an imposture, or fake.

\section{Implications for Language Planning and Policy}

While the goals of authenticity and unification in language planning are frequently viewed and portrayed as conflictive, they need not be. Since such tension is often deleterious to language planning efforts, it is worthwhile to attempt to diffuse the friction surrounding the issue of authenticity. In what follows we consider two avenues which may allow language planners and educational professionals to avoid or resolve the dilemmas described above. One such possibility is aimed at the corpus planning level (about the forms of the language); the other is directed at acquisition and status planning (about the norms of the language).

Turning first to the area of corpus planning, experience in minority and endangered language communities suggests that compromise on issues surrounding the language corpus is critical. A common confusion exists among many, including some language planners, that defence of the language corpus implies language maintenance or even language revitalisation. There is, however, no strong empirical connection between corpus and status preservation (Woolard, 1989). Rather to the contrary, recent work indicates 'that linguistic acculturation may in fact represent adaptation for survival' (1989: 365). Furthermore, Dorian (1994) and others (Hamp, 1989; Huffines, 1989) suggest that the absence of puristic attitudes may coincide with language longevity. It seems, then, that corpus planners would do well to heed Dorian's (1994) warning and 'to accept considerable compromise rather than make a determined stand for intactness' (492).

Applied to the Saraguro case this would mean allowing for greater 'give and take' between 'authentic' and Unified Quichua. Local language planners and advocates might consider taking a less rigorous stance in their vigilance against Spanish linguistic influence and reacting less critically towards deviations from Unified Quichua. In practice this would entail, for example, teachers' acceptance, rather than dismissal, of the local phonetic system and lexicon as produced by students in the more remote Quichua community schools, such as Tambopamba.

While interest in the Quichua corpus in and of itself is not harmful, such concern should not be at the expense of use of the language. Given the precarious state of the language, it is critical that Quichua be used and learned in the community. Any language planning efforts or actions for the sake of corpus purity which deter this from happening undermine the goal of revitalisation.

In Peru, corpus compromise would mean a willingness to suspend judgment on the matter of the three or five vowel alphabet, in favour of encouraging the greatest possible use of Quechua writing in whatever form. As long as the debate 
looms as an insurmountable impasse, it will have a dampening effect on creating a community of Quechua readers and writers. Such indeed was the case during the 1980s in Peru. For example, the Puno bilingual education project underwent the expense of revising and republishing their texts and reorienting their teacher training and classroom instruction to conform to the three-vowel decision made at the 1983 Workshop in Lima, only to find the decision continuing to be in question a few years later. The Summer Institute of Linguistics imposed a several-year moratorium on publications in Quechua while awaiting a final unified decision on the alphabet (the moratorium was lifted in late 1990 to allow publication in orthographies approved by departmental offices of education [Weber, personal communication, 2 October 1990]). Uncertainties about whether to publish and in which alphabet had obvious detrimental effects on the availability, consistency, and quality of Quechua language education and materials for Quechua learners.

Nevertheless, there is some evidence of an increasing recognition that the fundamental issue in promoting Quechua and its writing is in fact not the standardisation or unification of Quechua, but rather facilitation of its widespread and multi-faceted use. At a recent seminar on the teaching and learning of indigenous languages in Latin America, Peruvian linguist Cerrón-Palomino, in comparing the Quechua case to that of Euskera, the language of the Basque country (as presented by Idiazabal, 1996), noted that the rigid stances taken in the past with regard to a three versus five vowel alphabet had acted to stifle rather than stimulate the written development of Quechua and that it is rather tolerance and comprehension of dialectal usages that will ultimately guarantee the acceptance of consensually agreed upon forms (Cerrón-Palomino, 1996).

Turning to acquisition and status planning concerns, it is helpful to consider a critical distinction as drawn by Bentahila and Davies between two possible routes to achieving the language planning goal of revival: the process of restoration which attempts to return 'the language to a previously more healthy state and the process of transformation, which seeks to forge new roles for the language' (1993: 355). Often the vision of advocates for minority and threatened languages is one of restoring the threatened language to its former functional positions in the community. However, as Bentahila and Davies note, 'the chances of returning a declining language to its old domains in a restored speech community are very slim, so that if the term revival [or revitalisation] is interpreted in this sense, the whole enterprise may be dismissed as impractical and unrealistic' (1993: 371).

However, once it is recognised that return to the sociolinguistic situation of the past is an idealised and impossible goal, new and transformative ways of maintaining and revitalising the language can be considered:

The results may include the establishment of what is in effect a new variety of the language, used in new contexts, and adopted by a new type of speaker. It may no longer serve as the widely used medium of communication among the type of people with whom it was originally associated, but instead acquire new functions for another group, and be assigned roles it could never have assumed in its heyday. (Bentahila \& Davies, 1993:371) 
In a similar vein to that suggested in a session at the American Anthropological Association, organised in 1995 by Henze and Ernst on language revitalisation and entitled 'Bringing the Language Forward', we submit that those involved with language planning efforts would do well to embrace such a 'transformative' rather than a 'restorative' approach. Indeed, as we have argued elsewhere, language and education planning initiatives inherently involve bringing the language into new domains and using it in new ways (Hornberger \& King, 1996).

In the Saraguro context, embracing the transformative approach would entail not only acceptance, but also promotion of the idea that instruction of the language in the school, to a great extent, involves reconfiguring the distribution of Unified and 'authentic' Quichua. Language planners might consider establishing as a goal a diglossic situation wherein Unified Quichua is used for written communication and 'authentic' Quichua is employed in spoken interactions. Achievement of this aim would involve acceptance of 'authentic' and Unified varieties in spoken form (as suggested above), and continued academic instruction of Unified Quichua. Establishment of this type of diglossia has the benefit of promoting spoken communication across different sectors of the Saraguro population, permitting acquisition of the unified variety, enhancing intra-national written communication and literacy development, and thus allowing Quichua to evolve and grow across a range of media and contexts.

In Peru, acceptance of a transformative approach in the realm of language planning would likewise mean acceptance of multiple Quechua voices as legitimate speakers and users of Quechua. It would entail decision-making which includes both monolingual and bilingual speakers, both campesinos and indigenas, both SIL-educated and Ayacucho or Puno project-educated teachers and readers, both Lima linguists and Cusco Academy members. The Quechua voices will be many and varied, and they should be. If Quechua language planning is to succeed at transforming language use and challenging the politico-economic and sociocultural divisions in Peruvian society, then it must begin by transforming that use and challenging those divisions within itself.

Authenticity of the language, as an expression of a people's true face and voice, seems a goal worth striving for in language planning. Yet, as these Peruvian and Ecuadorian cases show, authenticity is neither unilateral nor unchanging, and is therefore not easily subject to fixing in time or space. To the degree that language planning efforts seek to unify and standardise language use according to unilateral norms and unchanging forms, they will not only fail, but worse, run the risk of harming the very languages they seek to protect. Rather, experience suggests that unification efforts must be directed towards ratifying the norms and forms which emerge out of the confluence of multiple streams of use of the language; in that way, unification becomes the complement to, rather than the adversary of authenticity.

\section{Correspondence}

Any correspondence should be directed to Professor Nancy H. Hornberger, Graduate School of Education, University of Pennsylvania, 3700 Walnut Street, Philadelphia, PA 19104-6216,USA (nancyh@gse.upenn.edu). 


\section{Notes}

1. Quechua is the term used to refer to the varieties spoken in Peru, Bolivia and parts of northern Chile; it is also the cover term for all varieties of the language. Quichua is used exclusively for varieties in Ecuador. The difference in terms has to do with the differing phonological evolution of the language in Ecuador, as compared to the other countries.

2. Standardisation refers to the 'development of a ... norm which overrides regional and social varieties', while graphisation entails the 'provision of a writing system for a hitherto unwritten language' (Ferguson, 1968; in Hornberger, 1994: 79). Both standardisation and graphisation refer here to corpus planning goals, not to be confused with the separate and distinct status planning goal of standardisation.

3. This debate has apparently been recently extended to Bolivia as well. For example Cotari (1996) 'Complejidad de la escritura quechua normalizada en la educación bilingüe' at http:/ / www.lostiempos.com/quechua/ling/ kimsphis.htm on the world wide web.

4. Hornberger (1995) describes this case in detail in a chapter in J. Tollefson (ed.) Power and Inequality in Education. We are grateful to Cambridge University Press for permission to reprint portions of the chapter here.

5. The indigenous groups of Ecuador self-identify as different 'nations', using the term to emphasise their distinct historical and political development and different sociocultural realities. Use of the term is also meant to imply rights of self-determination and autonomy (cf. May, this volume). Generally, these nations are made up of groups that share the same language. For example, the Otavalos of the northern Andes and the Saraguros of the southern Andes traditionally have spoken Quichua and both groups are part of the Quichua nation. Lowland nations such as the Huaorani and Shuar are distinguished from each other, in part by cultural beliefs and practices, but also by language.

6. Between 1972-1989 a Texaco consortium extracted and shipped 1.4 billion barrels of oil from the Amazon, comprising $88 \%$ of the oil taken from the region. During that time the Texaco pipeline leaked some 16.8 million gallons of raw crude into the delicate ecosystem (Kane, 1994). See Joe Kane's (1994) Savages and Judith Kimerling's (1991) Amazon Crude for a thorough and compelling discussion of the rapid environmental and cultural changes which have taken place in the region.

7. See Myers-Scotton's $(1983,1993)$ model for the interpretation of code-switches based on analysis of markedness, rights-and-obligations set, conversation implicature and the negotiation of identities.

\section{References}

Academia Mayor de la Lengua Quechua (1995) Diccionario Quechua/Español/Quechua. Qosqo, Peru: Municipalidad del Qosqo.

Belote, J. (1984) Changing adaptive strategies among the Saraguros of Southern Ecuador. Unpublished doctoral dissertation, University of Illinois, Illinois.

Bentahila, A. and Davies, E. (1993) Language revival: Restoration or transformation? Journal of Multilingual and Multicultural Development 14 (5), 355-73.

Cerrón-Palomino, R. (1996) Normalización y usos idiomáticos. Paper presented at Seminario internacional sobre el aprendizaje de lenguas en poblaciones indígenas en América Latina. Iquique, Chile, November.

CIA World Factbook (1997) World Wide Web page on Ecuador. (Http:/ /odci.gov/cia/publication).

CONAIE. (1990) Nucanchic Shimi 1. Quito: MEC; DINEIIB; CONAIE.

Cooper, R.L. (1989) Language Planning and Social Change. Cambridge: Cambridge University Press.

Cotari, D. (1996) Complejidad de la escritura quechua normalizada en la educación bilingüe. World WideWeb page(http:/ / www.lostiempos.com/quechua/ling/kimsphis.htm).

Debate: ¿Por qué el uso de las tres vocales en quechua? (1987) In Seminario Taller sobre 
Programas Curriculares para Educación Bilingüe: Informe Final (pp. 160-80). Lima, Peru: Ministerio de Educación - INIDE.

DINEIIB (Dirección Nacional de Educación Intercultural Indígena Bilingüe) (1991) La educación intercultural bilingüe en el Ecuador. Pueblos Indígenas y Educación 17, 31-67.

Dorian, N. (1994) Purism vs. compromise in language revitalization and language revival. Language in Society 23, 479-494.

Fishman, J. (1988) Ethnocultural issues in the creation, substitution, and revision of writing systems. In B. Rafoth and D. Rubin (eds) The Social Construction of Written Communication (pp. 273-86). Norwood, NJ: Ablex.

Hamp, E.P. (1989) On signs of health and death. In N. Dorian (ed.) Investigating Obsolescence (pp. 197-210). Cambridge: Cambridge University Press.

Hill, J. and Hill, K. (1980) Mixed grammar, purist grammar, and language attitudes in modern Nahuatl. Language in Society 9, 321-48.

Hornberger, N.H. (1993) The first workshop on Quechua and Aymara writing. In J. Fishman (ed.) The Earliest Stage of Language Planning: The First Congress Phenomenon (pp. 233-256). Berlin: Mouton de Gruyter.

Hornberger, N. (1994) Literacy and language planning. Language and Education 8 (1\&2), 75-86.

Hornberger, N. (1995) Five vowels or three? Linguistics and politics in Quechua language planning in Peru. In J. Tollefson (ed.) Power and Inequality in Language Education (pp. 187-205). Cambridge: Cambridge University Press.

Hornberger, N. and King, K. (1996) Bringing the language forward: School-based initiatives for Quechua language revitalization in Ecuador and Bolivia. In N. Hornberger (ed.) Indigenous Literacies in the Americas: Language Planning from the Bottom Up (pp. 299-320). Berlin: Mouton de Gruyter.

Huffines, M. (1989) Case usage among the Pennsylvania German sectarians and non-sectarians. In N. Dorian (ed.) Investigating Obsolescence (pp. 211-26). Cambridge: Cambridge University Press.

Idiazabal, I. (1996) Modernidad, desarrollo e idiomas minorizados: El caso del Euskera. Paper presented at Seminario internacional sobre el aprendizaje de lenguas en poblaciones indígenas en América Latina. Iquique, Chile, November.

ILV (Instituto Lingüístico de Verano) (1983) Consideraciones sobre el alfabeto general del quechua. Paper circulated at the I Taller de Escritura en Quechua y Aimara, Lima, Peru. October.

Inka Rimay: Organo de la Academia Peruana de la Lengua Quechua (1985) Cusco, Peru: Academia Peruana de la Lengua Quechua.

Inter-American Development Bank (1997) World Wide Web page. (http://www.iadb.org/).

Jung, I. and López, L. (1987) Aportes del proyecto de educación bilingüe-Puno a la discusión en torno al alfabeto Quechua. Allpanchis 29/30, 585-92 (In Primer congreso de la lengua quechua y lengua aymara. Cusco, 13-15 Febrero).

Kane, J. (1994) Savages. New York: Vintage Departures.

Kimerling, J. (1991) Amazon Crude. New York: Natural Resources Defense Council.

King, K. (1997) Language revitalization in the Andes: Quichua use, instruction, and identity in Saraguro, Ecuador. Unpublished doctoral dissertation, University of Pennsylvania.

López Flores, C. (1987) ¿Por Qué es Mejor Escribir Con Tres Vocales en Quechua? Lima, Peru: Ministerio de Educación - INIDE.

López, L.E. (1995) La Educación en Áreas ludigenas de América Latina: Apreciaciones Comparativas desde la Educación Bilingüe Intercultural. Guatemala: Centro de Estudios de la Cultura Maya.

Macas, L. (1993) Tenemos alma desde 1637. In D. Cornejo Menecho (ed.) Los Indios y el Estado-Pais (pp.111-134). Quito: Abya-Yala.

Montaluisa, L. (1980) El vocabulario general de la lengua Quichua para el Ecuador. Revista de la Universidad Católica 25,99-119.

Myers-Scotton, C. (1983) The negotiation of identities in conversation: A theory of markedness and code choice. International Journal of the Sociology of Language 44, 115-36. 
Myers-Scotton, C. (1993) Common and uncommon ground: Social and structural factors in code switching. Language in Society 22, 475-503.

Nahir, M. (1984) Language planning goals: A classification. Language Problems and Language Planning 8 (3), 294-327.

Parker, G. (1963) La clasificación genética de los dialectos quechuas. Revista del Museo Nacional 32, 241-52.

Pike, K. (1947) Phonemics: A Technique for Reducing Languages to Writing. Ann Arbor: University of Michigan Press.

Primer Congreso de la Lengua Quechua y Lengua Aymara (1987) Allpanchis 29/30, $581-92$.

Random House (1983) Webster's Encyclopedic Dictionary of the English Language. New York: Portland House.

Stewart, W. (1968) A sociolinguistic typology for describing national multilingualism. In J. Fishman (ed.) Readings in the Sociology of Language (pp.531-545). The Hague: Mouton.

Tamayo Herrera, J. (1980) Historia del Indigenismo Cuzqueño, Siglo XVI-XX. Lima, Peru: Instituto Nacional de Cultura.

Tamayo Herrera, J. (1982) Historia Sociale Indigenismo en el Altiplano. Lima, Peru: Ediciones Trentaitres.

Torero, A. (1974) El Quechua y la Historia Social Andina. Lima, Peru: Universidad Ricardo Palma.

Townsend, W. (1972) They Found a Common Language: Community through Bilingual Education. New York: Harper \& Row.

von Gleich, U. (1994) Language spread policy: The case of Quechua in the Andean republics of Bolivia, Ecuador, and Peru. International Journal of the Sociology of Language $107,77-113$.

Weber, D. (1987a) Comentarios sobre la Ortografía Quechua. Unpublished manuscript.

Weber, D. (1987b) Estudios Quechua: Planificación, Historia, y Gramática. Yarinacocha, Pucallpa, Peru: Ministerio de Educación, Instituto Lingüístico de Verano (Serie Lingüística Peruana \#27).

Woolard, K.A. (1989) Language convergence and language death as social processes. In N. Dorian (ed.) Investigating Obsolescence (pp. 355-67). Cambridge: Cambridge University Press.

Yáñez Cossío, C. (1991) The implementation of language policy: The case of Ecuador. International Review of Education 37 (1), 53-66. 